\title{
Renal Hormone Activity Alteration
}

National Cancer Institute

\section{Source}

National Cancer Institute. Renal Hormone Activity Alteration. NCI Thesaurus. Code C40616.

Any physiologic process that results in modulated activity of any of the renal hormones, including renin, erythropoietin, thrombopoietin and calcitriol. These processes are involved in regulation of blood pressure, production of red blood cells and platelets, and calcium homeostasis. 